\title{
Initial Synthesis and Characterization of an a7 Nicotinic Receptor Cellular Membrane Affinity Chromatography Column: Effect of Receptor Subtype and Cell Type
}

\author{
Ruin Moaddel ${ }^{\star}, \dagger$, Regina V. Oliveira ${ }^{\dagger} \neq$, Tomoko Kimura ${ }^{\dagger}$, Patrick Hyppolite $^{\dagger}$, Magdalena \\ Juhaszova $^{\dagger}$, Yingxian Xiao§, Kenneth J. Kellar§, Michel Bernier ${ }^{\dagger}$, and Irving W. Wainer ${ }^{\dagger}$ \\ Gerontology Research Center, National Institutes on Aging, National Institutes of Health, \\ Baltimore, Maryland 21224-6825, and Department of Pharmacology, Georgetown University \\ School of Medicine, Washington, D.C. 20057
}

\begin{abstract}
In this study, cellular membrane fragments from SH-EP1-pCEP4-ha7 and a7 HEK-293 cell lines were used to synthesize cellular membrane affinity chromatography (CMAC) columns containing functional a7 nicotinic acetylcholine receptors, $\mathrm{CMAC}(\mathrm{a} 7 \mathrm{nAChR})$ columns. The synthesis of stable columns required the addition of cholesterol to the $2 \%$ cholate solubilization/immobilization (s/i) buffer and to the mobile phase. In addition, when membranes from the SH-EP1 cell line were used, L-a-phosphatidylserine and L-a-phosphatidylethanolamine also had to be added to the s/i buffer. A CMAC $(\alpha 4 \beta 2 \mathrm{nAChR})$ column was prepared using membrane fragments from a SH-EP1pCEP4-ha $4 \beta 2$ cell line, and this process required the addition of L-a-phosphatidylserine and L-aphosphatidylethanolamine to the s/i buffer, but not cholesterol. The s/i buffers from the three columns were compared with the s/i buffer utilized in the preparation of a CMAC $(\alpha 4 \beta 2 \mathrm{nAChR})$ column prepared using an a $4 \beta 2$ HEK-293 cell line, which required no additions to the $2 \%$ cholate $\mathrm{s} / \mathrm{i}$ buffer. The data demonstrate that both cell type and receptor type affect the protocol required to produce a stable CMAC column and that, at the current time, the development of an optimum immobilization protocol is an empirical process. The results are also consistent with the observation that the a $7 \mathrm{nAChR}$ is localized in lipid rafts in both of these cell lines and that the cholate detergent removed cholesterol from these microdomains.
\end{abstract}

Neuronal nicotinic acetylcholine receptors (nAChRs) are ligand gated ion channels that are composed of five transmembrane subunits oriented around a central pore. ${ }^{1,2}$ To date, 12 different neuronal subunits have been identified, 9 a subunits (a2-a10) and $3 \beta$ subunits $(\beta 2-\beta 4)$. These subunits combine to form a wide variety of homomeric $a_{x}$ subtypes where $x$ $=7,9,10$ and heteromeric $\mathrm{a}_{x} \beta_{y}$ subtypes where $x=2,3,4,5,6$, and $y=2,3,4$.

The homomeric a $7 \mathrm{nAChR}$ is found in the mammalian brain, ${ }^{3}$ and these receptors appear to be involved in learning and memory ${ }^{4}$ and to play a role in Alzheimer's disease. ${ }^{5,6}$ The receptor is also involved in schizophrenia through the mediation of the release of GABA by

\footnotetext{
“To whom correspondence should be addressed. Phone: (410)-558-8294. Fax:(410)-558-8409. moaddelru@ grc.nia.nih.gov.

National Institutes of Aging.

\$Current address: Departamento de Química, Universidade Federal de São Carlos, São Carlos, SP, Brazil.

$\S_{\text {Georgetown University School of Medicine. }}$
} 
hippocampal interneurons, ${ }^{7}$ and a $7 \mathrm{nAChR}$ agonists such as clozapine are currently used in the clinical treatment of this disease. ${ }^{8}$ In the peripheral nervous system, the a $7 \mathrm{nAChR}$ has been implicated in the initial nicotine-induced heart rate decrease. ${ }^{9}$ In addition, a7 nAChRs have been associated with the regulation of inflammation through the inhibition of cytokine synthesis in the cholinergic anti-inflammatory pathway. ${ }^{10}$

The majority of the studies on the characterization of the human a $7 \mathrm{nAChR}$ have been carried out using electrophysiological techniques on receptors heterologously expressed in Xenopus oocytes. ${ }^{11,12}$ While the experimental procedures associated with this technique are demanding and time-consuming, this approach continues to be the predominant method for characterization of neuronal nAChRs.

An alternative approach to the study of the binding of agonists and antagonists to nAChRs is cellular membrane affinity chromatography (CMAC). ${ }^{13,14}$ In this experimental approach, cellular membrane fragments obtained from cell lines expressing the target nAChRs are immobilized on the surface of an immobilized artificial membrane (IAM) liquid chromatography stationary phase and the resulting nAChR-IAM stationary phases used to create the desired CMAC column. The columns are then used in frontal affinity chromatography or nonlinear chromatography studies to characterize ligand-nAChR interactions.

This technique has been used to produce CMAC columns containing heteromeric $a_{x} \beta_{y}$ subtypes, CMAC $\left(a_{x} \beta_{y} \mathrm{nAChR}\right)$ columns, containing the $\alpha 3 \beta 2, a 3 \beta 4, a 4 \beta 2$, and $\alpha 4 \beta 4$ nAChRs. ${ }^{15}$ The data from the studies with the $\operatorname{CMAC}\left(a_{x} \beta_{y} \mathrm{nAChR}\right)$ columns have demonstrated that this approach can be used to directly determine $K_{\mathrm{d}}$ values within and between $\alpha_{x} \beta_{y}$ nAChR subtypes, ${ }^{15}$ to sort compounds by relative $\mathrm{EC}_{50}$ values ${ }^{16}$ and to identify and characterize noncompetitive inhibitors of the nAChR. ${ }^{14}$

To date, CMAC columns containing homomeric nAChRs, such as the a $7 \mathrm{nAChR}$, have not been created. This article reports the synthesis and initial characterization of two CMAC(a7 nAChR) columns. The cellular membranes used in this study were obtained from an epithelial cell line, SH-EP1-pCEP4-ha7, and a human embryonic kidney cell line, KXa7HEK293. There were clear differences in the stabilities of the two CMAC $\left(a_{7} \mathrm{nAChR}\right)$ columns, which appeared to be due to the cell type. However, both of the CMAC $\left(a_{7}\right.$ $\mathrm{nAChR})$ columns were less stable than the previously described CMAC $\left(a_{x} \beta_{y} \mathrm{nAChR}\right)$ columns, even though one of the columns had been created using the same HEK293 cell type. Thus, it appeared that both cell type and receptor subtype played a role in the observed differences. Thus, this paper also reports the results of a comparative study using SH-EP1 and HEK293 cell lines that stably express either the a $7 \mathrm{nAChR}$ or $\alpha 4 \beta 2 \mathrm{nAChR}$ designed to examine the sources of these differences. The data indicate that both cell type and receptor subtype play a role in the observed stability, and the results demonstrate that the creation of CMAC columns must be undertaken with an understanding of the biological and pharmacological properties of the target and the expression system. 


\section{MATERIALS AND METHODS}

\section{Materials}

Phenylmethylsulfonyl fluoride (PMSF), benzamidine, leupeptin, ( \pm )-epibatidine (EB), $(S)$ nicotine tartrate (NIC), cholesterol, fluorescent isothiocyanate (FITC)-labeled-abungarotoxin (FITC-aBgt), cholic acid sodium salt, and ethylenediaminetetraacetic acid (EDTA) were purchased from Sigma Aldrich (St. Louis, MO). L-a-Phosphatidylserine and L-a-phosphatidylethanolamine were purchased from Avanti Lipids (Alabastar, AL). [ $\left.{ }^{3} \mathrm{H}\right]-$ EB $(66.6 \mathrm{Ci} / \mathrm{mmol})$ and $\left[{ }^{3} \mathrm{H}\right]-\mathrm{NIC}(86.7 \mathrm{Ci} / \mathrm{mmol})$ were purchased from NEN Life Science Products (Boston, MA). Dulbecco's modified Eagle's medium 1× (DMEM) and sodium pyruvate was purchased from Invitrogen Corp. (Carlsbad, CA). Horse serum, fetal bovine serum, and amphotericin B were purchased from Biosource International (Rockville, MD). Immobilized artificial membrane (IAM-PC) silica beads ( $12 \mu \mathrm{m}$ particle size, $300 \AA$ pore size) were from Regis Technologies Inc. (Morton Grove, IL). Nitrocellulose dialysis tubing (MW cutoff < 10000 Da) was purchased from Pierce Chemical (Rockford, IL).

Chromatographic glass columns HR 5/2 and a 50-mL superloop were purchased from Amersham Pharmacia Biotech (Uppsala, Sweden).

\section{Cell Line}

The SH-EP1, SH-EP1-pCEP4-ha4 $\beta 2$ and SH-EP1-pCEP4-ha7 cell lines used in this study were kindly provided by R. Lukas (Division of Neurobiology, Barrow Neurological Institute, Phoenix, AZ), and the HEK-293 cell line was obtained from American Type Tissue Culture (Manassas, VA). The cell lines were maintained following a previously described procedure, ${ }^{17}$ in which the cells were grown in DMEM supplemented with $10 \%$ horse serum, $5 \%$ fetal bovine serum, $1 \%$ sodium pyruvate, and $8 \%$ amphotericin B.

\section{Immobilization of Cellular Membrane Fragments}

The membranes obtained from the SH-EP1, SH-EP1-pCEP4-ha7, SH-EP1-pCEP4-ha4 $\beta 2$, ha7HEK-293, ha4/2HEK-293, and HEK-293 cells were immobilized on the IAM stationary phase following a previously described method, ${ }^{15}$ which was modified as needed for the different cell lines and receptor subtypes. In brief, $(10-30) \times 10^{6}$ cells were placed in $10 \mathrm{~mL}$ of Tris- $\mathrm{HCl}$ buffer (50 mM, pH 7.4) containing $5 \mathrm{mM}$ EDTA, $3 \mathrm{mM}$ benzamidine, and $0.2 \mathrm{mM}$ PMSF. The suspension was homogenized for $3 \times 15 \mathrm{~s}$ at the setting of $12.5 \mathrm{on}$ a model PT-2100 homogenizer (Kinematica AG, Luzern, Switzerland). The homogenate was centrifuged at $800 \mathrm{~g}$ for $4 \mathrm{~min}$, and the pellet containing the nuclear proteins was discarded. The supernatant was centrifuged at $100000 \mathrm{~g}$ for $20 \mathrm{~min}$ at $4{ }^{\circ} \mathrm{C}$, and the resulting pellet containing the cellular membranes was collected and resuspended in $10 \mathrm{~mL}$ of one of the following solubilization buffers: (a) SH-EP1-pCEP4-ha7, SH-EP1. Tris-HCl buffer (50 mM pH 7.4), containing $2 \mathrm{mM} \mathrm{MgCl}_{2}, 100 \mathrm{mM} \mathrm{NaCl}, 3 \mathrm{mM} \mathrm{CaCl}_{2}, 5 \mathrm{mM} \mathrm{KCl}, 10 \mu \mathrm{M}$ leupeptin, $100 \mathrm{nM}$ cholesterol, $60 \mu \mathrm{M}$ L-a-phosphatidylserine, $40 \mu \mathrm{M} \mathrm{L-a-}$ phosphatidylethanolamine, and 2\% (w/v) cholate. (b) SH-EP1-pCEP4-ha4 $\beta 2$. Tris-HCl buffer (50 mM pH 7.4), containing $2 \mathrm{mM} \mathrm{MgCl}_{2}, 100 \mathrm{mM} \mathrm{NaCl}, 3 \mathrm{mM} \mathrm{CaCl}_{2}, 5 \mathrm{mM} \mathrm{KCl}$, $10 \mu \mathrm{M}$ leupeptin, $60 \mu \mathrm{M}$ L-a-phosphatidylserine, $40 \mu \mathrm{M}$ L-a-phosphatidylethanolamine, and $2 \%$ (w/v) cholate. (c) ha7 HEK-293, HEK-293. Tris-HCl buffer (50 mM pH 7.4), containing $2 \mathrm{mM} \mathrm{MgCl}_{2}, 100 \mathrm{mM} \mathrm{NaCl}, 3 \mathrm{mM} \mathrm{CaCl}_{2}, 5 \mathrm{mM} \mathrm{KCl}, 10 \mu \mathrm{M}$ leupeptin, 100 
$\mathrm{nM}$ cholesterol, $60 \mu \mathrm{M}$ L-a-phosphatidylserine, $40 \mu \mathrm{M}$ L-a-phosphatidylethanolamine, and $2 \%$ (w/v) cholate. (d) ha4 $\beta 2$ HEK-293. Tris- $\mathrm{HCl}$ buffer ( $50 \mathrm{mM} \mathrm{pH} 7.4$ ), containing $2 \mathrm{mM}$ $\mathrm{MgCl}_{2}, 100 \mathrm{mM} \mathrm{NaCl}, 3 \mathrm{mM} \mathrm{CaCl} 2,5 \mathrm{mM} \mathrm{KCl}, 10 \mu \mathrm{M}$ leupeptin, and 2\% (w/v) cholate.

The resulting mixture rotated at $150 \mathrm{rpm}$ using an orbit shaker (Lab-line model 3520, Melrose Park, IL) for $18 \mathrm{~h}$ at $4{ }^{\circ} \mathrm{C}$ and subsequently centrifuged at $80000 \mathrm{~g}$ for $20 \mathrm{~min}$, and the supernatant containing membrane-cholate solution was collected. The supernatant was mixed with $200 \mathrm{mg}$ of the IAM stationary phase; the resulting mixture was rotated at room temperature for $1 \mathrm{~h}$ at $150 \mathrm{rpm}$ using an orbit shaker and then dialyzed against $1 \mathrm{~L}$ of Tris $\mathrm{HCl}\left(50 \mathrm{mM}\right.$, pH 7.4) containing $100 \mathrm{mM} \mathrm{NaCl}, 5 \mathrm{mM}$ EDTA, $0.1 \mathrm{mM} \mathrm{CaCl}_{2}$, and 0.02 mM PMSF for 1 day at $4{ }^{\circ} \mathrm{C}$. The resulting mixture was centrifuged for 3 min at $400 g$, and the supernatant was discarded. The pellet was washed with $5 \mathrm{~mL}$ of Tris- $\mathrm{HCl}(10 \mathrm{mM}, \mathrm{pH}$ 7.4) and centrifuged. This process was repeated until the supernatant was clear.

The IAM supports were collected and packed into HR 5/2 chromatographic glass columns to create the respective CMAC columns containing $18 \mathrm{~mm} \times 5 \mathrm{~mm}$ I.D chromatographic beds.

\section{Frontal Chromatographic Studies}

(1) Chromatographic System-The CMAC columns were placed in a chromatographic system, which has been previously described. ${ }^{15}$ The mobile phase consisted of ammonium acetate (10 mM, pH 7.4), which contained $10 \mathrm{pM}$ cholesterol when the CMAC(ha7-SHEP1), CMAC(ha7 HEK-293), and CMAC(ha4 $\beta 2$-SH-EP1) columns were used. The mobile phase was delivered at $0.2 \mathrm{~mL} / \mathrm{min}$ at room temperature, and the CMAC column was washed for $18 \mathrm{~h}$ between injections. Detection of the marker ligands $\left[{ }^{3} \mathrm{H}\right]$-EB or $\left[{ }^{3} \mathrm{H}\right]$-NIC was accomplished using an on-line scintillation detector (IN/US system, $\beta$-ram model 3, Tampa, FL) with a dwell time of $2 \mathrm{~s}$ using Laura lite 3.

(2) Chromatographic Studies-On the CMAC(a7 nAChR) columns, the marker ligand for the frontal chromatographic studies of NIC was [ $\left.{ }^{3} \mathrm{H}\right]-\mathrm{NIC}(120 \mathrm{pM})$ and $10-\mathrm{mL}$ solutions containing the marker ligand and a series of concentrations of NIC, 0.50, 1.0, 10, 5, 0.050, 0.100 , and $0.500 \mathrm{nM}$, were applied to the columns. For studies involving EB, the concentration of the marker ligand $\left(\left[{ }^{3} \mathrm{H}\right]-\mathrm{EB}\right)$ was $120 \mathrm{pM}$ and the concentrations of EB were $60 \mathrm{pM}, 100 \mathrm{pM}, 1 \mathrm{nM}$, and $5 \mathrm{nM}$.

On the CMAC $\left(a 4 \beta 2\right.$ nAChR) columns, the marker ligand was $\left[{ }^{3} \mathrm{H}\right]-\mathrm{EB}(30 \mathrm{pM})$ and the concentrations of displacers were EB 15, 30, 60, 120, and $180 \mathrm{pM}$; and NIC 0.1, 1, 5, 10, and $50 \mathrm{nM}$.

(3) Data Analysis-The data were analyzed as previously described. ${ }^{15}$

\section{Confocal Microscopy and a-Bungarotoxin Binding}

FITC-a-Bgt (1 mg/mL) was pumped through the CMAC columns created using the SH-EP1 and SH-EP1-pCEP4-ha7, ha7 HEK-293, and HEK-293 cell lines for 30 min using a peristaltic pump (Dynamax RP-1) at a flow rate of $50 \mu \mathrm{L} / \mathrm{min}$, followed by water for $30 \mathrm{~min}$. A small amount of stationary phase was collected and analyzed by confocal microscopy. The stationary phases were imaged with a Zeiss LSM-410 inverted confocal microscope 
(Carl Zeiss Inc., Jena, Germany) with excitation at $488 \mathrm{~nm}$ and collecting emission at greater than $515 \mathrm{~nm}$ simultaneously with transmitted image using a Zeiss Plan-Apochromat 63×/1.4 NA oil immersion lens. The images were processed by MetaMorph software (Universal Imaging Corp., Downingtown, PA).

\section{RESULTS}

\section{Preparation of CMAC(a7 nAChR) Columns}

In the previous studies on the synthesis and characterization of CMAC $\left(a_{x} \beta_{y} \mathrm{nAChR}\right)$ columns, (1-3) $\times 10^{6}$ HEK-293 cells expressing the target $a_{x} \beta_{y} \mathrm{nAChR}$ were required to produce a viable column. ${ }^{15}$ Based on these results, the initial preparation of the CMAC $(a 7$ $\mathrm{nAChR}$ ) columns was carried out using membranes obtained from $3 \times 10^{6}$ cells from either the SH-EP1-ha7 cell line or the KXa7-HEK-293 cell line. However, no measurable binding activity was observed on either CMAC column. In order to determine if this was due to the level of expression of the a $7 \mathrm{nAChRs}$ in the respective cell lines, the number of cells used in the preparation of the CMAC columns was sequentially increased. Using $\left[{ }^{3} \mathrm{H}\right]$-EB as the marker ligand, measurable binding activity was observed with columns prepared from (2030) $\times 10^{6}$ of SH-EP1-ha7 cells and $10 \times 10^{6}$ KXa7-HEK-293 cells.

In the protocol employed in the synthesis and characterization of $\operatorname{CMAC}\left(\mathrm{a}_{x} \beta_{y} \mathrm{nAChR}\right)$ columns, initial frontal displacement chromatography studies are used to establish the apparent affinity, $K_{\mathrm{d}}$, of the immobilized nAChRs for $\left[{ }^{3} \mathrm{H}\right]-\mathrm{EB}$, established nAChR marker ligand. When the CMAC(a7 nAChR) column prepared using SH-EP1-ha7 cells was studied, the characteristic frontal chromatography curves with initial flat, breakthrough, and plateau regions were observed. However, although the data indicated that EB was specifically retained on the CMAC(a $7 \mathrm{nAChR})$ column, the calculated $K_{\mathrm{d}}$ for $\mathrm{EB}, 80 \mathrm{nM}$, was significantly weaker than the $K_{\mathrm{d}}$ of $0.64 \mathrm{nM}$ previously reported for the SH-EP1-ha7 cells. ${ }^{17}$ Further, the $K_{\mathrm{d}}$, value for NIC could not be obtained due to a continuous decrease in the observed specific retention of $\left[{ }^{3} \mathrm{H}\right]-\mathrm{EB}$. The unstable behavior of the column suggested that the protocol used in the synthesis of the CMAC column had affected the stability of the membrane fragments, a $7 \mathrm{nAChRs,} \mathrm{or} \mathrm{both.}$

In previous studies involving G-protein-coupled receptors (GPCRs), the addition of mixed egg phosphatidylcholine (PC) and phosphatidylserine (PS) lipids to the solubilization and chromatographic buffers was required to produce stable CMAC columns. ${ }^{18,19}$ This approach was used in this study, and the membranes from the SH-EP1-ha7 cells were stabilized by the addition of $100 \mathrm{nM}$ cholesterol, $60 \mu \mathrm{M}$ L-a-phosphatidylserine, and $30 \mu \mathrm{M} \mathrm{L-a-}$ phosphatidylethanolamine to the solubilization buffer. Once the protocol was developed for the SH-EP1-ha7 cells, the same approach was applied to the synthesis of the CMAC(a7 nAChR) from the KXa7HEK-293 cells. However, this cell line only required the addition of cholesterol to the solubilization buffer.

\section{Characterization of CMAC(a7 nAChR) Columns}

The activity and selectivity of the $\mathrm{CMAC}(\mathrm{a} 7 \mathrm{nAChR})$ columns were determined using frontal displacement studies employing both $\left[{ }^{3} \mathrm{H}\right]-\mathrm{NIC}$ and $\left[{ }^{3} \mathrm{H}\right]-\mathrm{EB}$ as the marker ligands 
and NIC and EB as the displacers, cf. Figure 1. Elution profiles containing front and plateau regions were observed, and the relationship between the concentrations of the displacer and the corresponding breakthrough volumes of the marker was used to calculate the $K_{\mathrm{d}}$ values for the displacer as previously described. ${ }^{15}$ However, the observed affinity of EB on the CMAC column prepared using the SH-EP1-ha7 cells, was still weaker than the expected value. This was addressed by the addition of $10 \mathrm{pM}$ cholesterol to the chromatographic mobile phase. Under these conditions, the observed binding affinity for EB increased as the calculated $K_{\mathrm{d}}$ value decreased from 80 to $0.67 \mathrm{nM}$, Table 1 . This value was consistent with the previously reported $K_{\mathrm{d}}$ value of $0.64 \mathrm{nM}$ obtained using membranes obtained from SHEP1-ha7 cells and competitive membrane binding techniques. ${ }^{17}$ This is not surprising as both methods used membranes obtained from the SH-EP1-ha7 cell line, the same marker, $\left[{ }^{3} \mathrm{H}\right]-\mathrm{EB}$, and the same general experimental approach, i.e., competitive binding.

The $K_{\mathrm{d}}$ values for EB and NIC were determined on both CMAC(a7 nAChR) columns, Table 1. There was no significant difference between the $K_{\mathrm{d}}$ values for EB determined on the two columns. There was also no significant difference between the calculated $K_{\mathrm{d}}$ values for NIC, which were $\sim 7 \mu \mathrm{M}$. The $K_{\mathrm{d}}$ values for the binding of NIC to the human a $7 \mathrm{nAChR}$ used in this study have not been reported, and no direct comparison can be made with the data from membrane binding studies. However, in a study using a $7 \mathrm{nAChR}$ immunopurified from chick retina and [ $\left.{ }^{125} \mathrm{I}\right]$-a-bungarotoxin as the marker, NIC displayed a $K_{\mathrm{i}}$ value of $1.2 \mu \mathrm{M} .{ }^{11}$ Thus, the results indicate that the $\mathrm{CMAC}(\mathrm{a} 7 \mathrm{nAChR})$ columns developed in this study can be used to determine the binding affinities of compounds at the a $7 \mathrm{nAChR}$.

\section{Preparation and Characterization of $\mathrm{CMAC}(\alpha 4 \beta 2 \mathrm{nAChR})$ Columns}

Following the protocol developed for the immobilization of the membrane fragments from the SH-EP1-ha7 cell line, $(20-30) \times 10^{6}$ SH-EP1-ha4 $\beta 2$ cells were used in the synthesis of the CMAC $(\alpha 4 \beta 2 \mathrm{nAChR})$ column. A systematic examination of the solubilization and immobilization parameters indicated that while L-a-phosphatidylserine and L-aphosphatidylethanolamine were necessary in the solubilization buffer, it was not necessary to add cholesterol to this buffer. The synthesis of the CMAC- $(a 4 \beta 2$ nAChR) column from the ha $4 \beta 2$ HEK- 293 cell line has been previously reported ${ }^{15}$ and was accomplished using membranes from $1 \times 10^{6}$ to $3 \times 10^{6}$ cells and did not require the addition of lipids to the solubilization buffer.

The nAChR binding affinities on the CMAC $(\alpha 4 \beta 2 \mathrm{nAChR})$ columns were characterized using EB and NIC, Table 1. On the CMAC (a $4 \beta 2$ nAChR) column created using the SHEP1-ha $4 \beta 2$ cell line, the $K_{\mathrm{d}}$ value for EB was $0.46 \mathrm{nM}$ and the $K_{\mathrm{d}}$ value for NIC was 12.8 $\mathrm{nM}$. These values were consistent with the $K_{\mathrm{d}}$ values of 0.49 and $76 \mathrm{nM}$, respectively, determined using competitive binding experiments with SH-EP1-ha $4 \beta 2$ membranes and $\left[{ }^{3} \mathrm{H}\right]$-EB as the marker ligand. ${ }^{17}$ On the previously reported CMAC- $(\alpha 4 \beta 2 \mathrm{nAChR})$ column created using a $4 \beta 2 \mathrm{HEK}-293$ cells, the $K_{\mathrm{d}}$ value for EB was $0.01 \mathrm{nM}$ and the $K_{\mathrm{d}}$ value for NIC was $16.4 \mathrm{nM}$. These values were consistent with the $K_{\mathrm{d}}$ values of 0.06 and $10 \mathrm{nM}$, respectively, determined using competitive binding experiments with a4 $\beta 2$ HEK-293 membranes and $\left[{ }^{3} \mathrm{H}\right]-\mathrm{EB}$ as the marker ligand. ${ }^{20}$ The data indicate that the immobilized 
$a 4 \beta 2 \mathrm{nAChRs}$ retained their ability to bind ligands and that there were no significant differences between the observed affinities on the two CMAC $(a 4 \beta 2$ nAChR $)$ columns.

\section{Confocal Microscopy}

In the previous studies of $\mathrm{CMAC}\left(\mathrm{a}_{x} \beta_{y} \mathrm{nAChR}\right)$ columns, the presence of the cellular membranes and immobilized receptors on the surface of the silica beads was not visualized, in part due to the lack of an appropriate fluorescent marker. However, the expression of functional ha7 nAChRs on the cellular surface of macrophages has been recently demonstrated using a fluorescently labeled isothiocyanate derivative of a-bungarotoxin (FITC-a-Bgt) and fluorescent confocal microscopy. ${ }^{10}$ This approach was employed in this study using the IAM stationary phases used to create the CMAC (a7 nAChR) columns from the SH-EP1-ha7 and a7HEK-293 cell lines. In order to ensure that nonspecific binding on the cellular surfaces did not produce false positive staining, membranes obtained from nontransfected SH-EP1 and HEK-293 cell lines were also immobilized on the IAM stationary phase using the same conditions employed with the respective transfected cell line.

The $12-\mu \mathrm{m}$ silica beads, which comprise the backbone of the IAM stationary phase, were clearly evident when the IAM phase coated with membranes from the SH-EP1-ha7 was imaged without fluorescent light, Figure 2A. Similar results were obtained with the other three phases (data not shown). Under fluorescent conditions, the measured emission at $\lambda>$ $515 \mathrm{~nm}$ from the IAM phases containing membranes from the SH-EP1-ha7 and a7 HEK-293 cell lines, Figure 2B, E, were significantly greater than the emissions from the corresponding IAM phase containing membranes from the respective nontransfected cell lines, Figure 2C, F. The results indicate that the membrane fragments from the SH-EP1-ha7 and a7HEK-293 cell lines coated the IAM phase and retained the ability to bind a specific a7 nAChR marker.

It is of interest to note that a comparison of the IAM beads coated with the SH-EP1-ha7 membrane fragments imaged without fluorescent light (Figure 2A) with the number of particles observed under fluorescent imaging (Figure 2B) indicated that functional ha7 nAChRs were present in $\sim 60 \%$ of the IAM particles. The observed surface coverage on the IAM particles can be attributed to the immobilization technique. After detergent solubilization, no further attempts were made to purify the homogenized membranes. Thus, it is likely that membranes fractions that did not contain the expressed ha7 nAChRs were immobilized on the surface of the IAMs, thereby reducing the area available for the immobilization of membrane fractions containing active receptors. Further, the level of expression obtained with the SH-EP1 cells was only $80 \% .{ }^{16}$

\section{DISCUSSION}

In previous studies, membrane fragments from HEK-293 cell lines expressing heteromeric $\mathrm{a}_{x} \beta_{y} \mathrm{nAChRs}$ were used to create $\operatorname{CMAC}\left(\mathrm{a}_{x} \beta_{y} \mathrm{nAChR}\right)$ columns. In these studies, the membrane fragments were solubilized using a $2 \%$ cholate buffer and then immobilized on IAM beads by removing the detergent with dialysis. This protocol did not work when applied to the immobilization of the cellular membranes obtained from the SH-EP1-ha7 
cells, and lipids had to be added to the solubilization buffer in order to stabilize the membrane fragments and retain a $7 \mathrm{nAChR}$ function. Since both the cell line and the receptor subtype differed between the two experiments, it was not immediately clear which factor was responsible for the necessary changes in the solubilization/immobilization buffer. In order to examine this question, CMAC columns were produced using membranes obtained from a7 HEK-293, SH-EP1-ha7, and SH-EP1-ha4 $\beta 2$ cell lines and the data from the three columns were compared to the previous results obtained using the a $4 \beta 2$ HEK-293 cell line. ${ }^{15}$ The data are presented in Table 2. It is important to note that once the immobilization processes and the mobile-phase conditions had been optimized, the observed affinities of the immobilized receptor subtypes were essentially equivalent and independent of the source of the cellular membrane, Table 1 . Thus, the answers lie in the immobilization process.

The solubilization/immobilization buffer used with both of the SH-EP1 cell lines required the addition of PS and PE lipids. In contrast, these lipids were not required when HEK-293 cells were the source of the membrane fragments. The data suggest that a key factor is the composition of the cellular membrane.

The comparison of the results from the point of view of the nAChR subtypes adds another dimension to this analysis. With the a $7 \mathrm{nAChRs,} \mathrm{it} \mathrm{was} \mathrm{necessary} \mathrm{to} \mathrm{add} \mathrm{cholesterol} \mathrm{to} \mathrm{both}$ the solubilization/immobilization buffers and mobile phase irrespective of the source of the cellular membranes, while this was not required with the $a 4 \beta 2$ subtypes. The observation that the addition of cholesterol was essential to achieve a stable a $7 \mathrm{nAChR}$ suggests that this subtype is located in an environment, or microdomain, different from the a $4 \beta 2 \mathrm{nAChRs}$ within the cellular membranes.

Membrane microdomains composed of sphingolipids, cholesterol, glycolipids, and proteins have been identified and shown to provide an ordered lipid environment within the membrane and to play key roles in signal transduction, transcellular transport, and cholesterol homostasis. ${ }^{21-23}$ These microdomains are a group of related structures, lipid rafts, which have been classified on the basis of the presence or absence of caveolin within the structure, and designated as caveolae or lipid rafts, respectively. However, the biological significance of this designation has not been firmly established.

Proteomic studies of lipid rafts and caveolae have demonstrated that these structures are highly complex and diverse. ${ }^{23-25}$ It has also been shown that detergent extraction removes some lipids and proteins from rafts and that the extractability of proteins from rafts can be used to probe the variability in lipid raft structure. ${ }^{23,26}$ These rafts can also be disrupted by the methyl- $\beta$-cyclodextrin-mediated extraction of cholesterol. ${ }^{22}$

A number of GPCRs, ion channels, and enzymes have been found in caveolae and lipid rafts. ${ }^{27}$ The association of lipid rafts and $\mathrm{a} 7 \mathrm{nAChR}$ has also been demonstrated in somatic spines of ciliary neurons ${ }^{28}$ and in PC- 12 cells. ${ }^{29}$ The latter studies with the PC-12 cell line are particularly relevant to the present work. The PC-12 cells have been shown to express both homomeric (a7) and heteromeric ( $\alpha 3, \alpha 5, \beta 2, \beta 4) \mathrm{nAChR}$ subunits, and the presence of functional $\mathrm{a} 7 \mathrm{nAChR}$ was also demonstrated. In addition, caveolin of any subtype was not 
detected in the cell line. When the lipid rafts were prepared using sucrose gradient centrifugation, only the $\mathrm{a} 7 \mathrm{nAChR}$ was found in the rafts. In addition, cholesterol depletion disrupted the receptor's activity. The authors concluded that the a $7 \mathrm{nAChRs}$ were localized to the lipid rafts while the other receptor subunits were located in other microdomains of the plasma membrane.

In this study, the synthesis of stable $\mathrm{CMAC}(\mathrm{a} 7 \mathrm{nAChR})$ columns from membrane fragments obtained from both the SH-EP1 and HEK-293 cell lines required the addition of cholesterol to the solubilization/immobilization buffers and to the mobile phase. This is consistent with the observation that the a $7 \mathrm{nAChR}$ is localized in lipid rafts in both of these cell lines and that the cholate detergent removed cholesterol from these microdomains. Indeed, cholate has been shown to effectively remove cholesterol during membrane solubilization and would be expected to affect these domains. ${ }^{30}$

The fact that the synthesis of stable CMAC $(\alpha 4 \beta 2 \mathrm{nAChR})$ columns from membrane fragments obtained from both the SH-EP1 and HEK-293 cell lines did not require the addition of cholesterol to the solubilization/immobilization buffers is also consistent with the previous observation that heteromeric subunits of the nAChR are not located within lipid rafts.

The results of this study also demonstrate that, since lipid rafts exist within a membrane environment, disruption of this environment will also destabilize the receptor. Thus, it is likely that the PS and PE lipids were extracted during cholate solubilization. This disrupted the membrane structure of the SH-EP1 cells requiring the addition of these lipids to the solubilization/immobilization buffers in order to stabilize the membrane fragments. It is of interest that this did not occur during the solubilization of the HEK-293 membrane fragments indicating that the HEK-293 cell line has a different membrane architecture and suggesting that it might be preferred over the SH-EP1 cell line in the development of CMAC columns.

Thus, it appears that both cell type and receptor affect the protocol required to produce a stable CMAC column and that these requirements reflect the membrane localization of the receptor. This observation is consistent with a previous study on the development of a CMAC column from membrane fragments obtained from a HEK-293 cell line expressing the $\beta_{2}$-adrenergic receptor $\left(\beta_{2}\right.$-AR). ${ }^{19}$ In this study, the preparation of a stable CMAC column required the addition of mixed egg PC to the solubilization/immobilization and chromatographic buffers, Table 2 . The $\beta_{2}$-AR is a GPCR that has been identified in caveolin-3 containing lipid rafts in neonatal rat cardiomyocytes, ${ }^{31}$ while a second GPCR, the $\mathrm{D}_{1}$ dopamine receptor, localized in caveolin-2 containing lipid rafts in the HEK-293 cell line. ${ }^{28}$ In addition to cholesterol, the cholate detergent effectively removes phosphatidyl lipids from cellular membranes ${ }^{30}$ and the required addition of PC to the solubilization/ immobilization and chromatographic buffers suggests that, in the HEK-293 cell line used in the study, the $\beta_{2}$-AR was localized to a lipid raft containing a caveolin subtype. It is of interest to note that the same protocol was required when the cholate detergent was replaced by CHAPS, which has a detergent extractability profile that is similar to cholate. ${ }^{30}$ 
The results with the $\beta_{2}$-AR and the nAChRs discussed in this study indicate that, at the current time, the development of an optimum immobilization protocol is an empirical process. This is emphasized by the development of a CMAC column containing the $\mathrm{P} 2 \mathrm{Y}_{1}$ receptor, a GPCR, which was produced using cellular membrane fragments obtained from the $1321 \mathrm{~N} 1$ astrocytoma cell line. ${ }^{32}$ In this case, the detergent was $n$-octyl $\beta$-Dglucopyranoside and it was not necessary to add lipids to the solubilization/immobilization buffer. This may be due to the cell type, the membrane localization of the $\mathrm{P}_{2} \mathrm{Y}_{1}$ receptor, or the fact that $n$-octyl $\beta$-D-glucopyranoside has a different detergent extractability profile than cholate and CHAPS. These factors are under investigation, and the results will be reported elsewhere.

While the empirical nature of the process may require added experimentation, the resulting CMAC columns are an interesting and useful addition to receptor-ligand studies. The optimized CMAC(a7 nAChR) columns produced in this study were viable for over 1 month and have been used in a variety of studies. These results will also be published elsewhere.

\section{Acknowledgments}

This research was supported in part by the Intramural Research Program of the NIH, National Institute on Aging.

\section{References}

1. Holladay MW, Dart MJ, Lynch JK. J Med Chem. 1997; 40:4169-4194. [PubMed: 9435889]

2. Hucho F, Tsetlin VI, Machold J. Eur J Biochem. 1996; 239:539-557. [PubMed: 8774696]

3. Lukas RJ, Changeux JP, Le Novere N, Albuquerque EX, Balfour DJ, Berg DK, Bertrand D, Chiappinelli VA, Clarke PB, Collins AC, Dani JA, Grady SR, Kellar K, Lindstrom JM, Marks MJ, Quik M, Taylor PW, Wonnacott S. Pharmacol Rev. 1999; 51:397-401. [PubMed: 10353988]

4. Radcliffe KA, Dani JA. J Neurosc. 1998; 18:7075-7083.

5. Kihara T, Shimohama S, Sawada H, Honda K, Nakamizo T, Shibasaki H, Kume T, Akaike A. J Biol Chem. 2002; 276:13541-13546. [PubMed: 11278378]

6. Picciotto MR, Zoli M. J Neurobiol. 2002; 53:641-655. [PubMed: 12436427]

7. Martin LF, Kem WR, Freedman R. Psychopharmacology. 2004:54-64. [PubMed: 15205879]

8. Simosky JK, Stevens KE, Adler LE, Freedman R. Psychopharmacology. 2003; 165:386-396. [PubMed: 12459928]

9. Ji S, Tosaka T, Whitfield BH, Katchman AN, Kandil A, Knollmann BC, Ebert SN. J Pharm Exp Ther. 2002; 301:893-899.

10. Wang H, Yu M, Ochani M, Amella CA, Tanovic M, Susaria S, Li JH, Wang H, Yang H, Ulloa L, Al-Abed Y, Czura CJ, Tracey KJ. Nature. 2003; 421:384-388. [PubMed: 12508119]

11. Gerzanich V, Peng X, Wang F, Wells G, Anand R, Fletcher S, Lindstrom J. Mol Pharm. 1995; 48:774-782.

12. Papke RL, Sanberg PR, Shytle RD. J Pharm Exp Ther. 2001; 297:646-656.

13. Moaddel R, Jozwiak K, Wainer IW. Med Res Rev. 2007; 27:723-753. [PubMed: 17238157]

14. Jozwiak K, Haginaka J, Moaddel R, Wainer IW. Anal Chem. 2002; 74:4618-4624. [PubMed: 12349962]

15. Moaddel R, Jozwiak K, Whittington K, Wainer IW. Anal Chem. 2005; 77:895-901. [PubMed: 15679359]

16. Moaddel R, Jozwiak K, Yamaguchi R, Cobello C, Whittington K, Sarkar T, Basak S, Wainer IW. J Chromatogr, B. 2004; 813:235.

17. Peng JH, Fryer JK, Hurst RS, Schroeder KM, George AA, Morrissy S, Groppi VE, Leonard SS, Lukas RJ. J Pharm Exp Ther. 2005; 313:24-35. 
18. Beigi F, Wainer IW. Anal Chem. 2004; 75:4480-4485. [PubMed: 14632053]

19. Beigi F, Chakir K, Xiao RP, Wainer IW. Anal Chem. 2004; 76:7187-7193. [PubMed: 15595859]

20. Zhang YX, Xiao YX, Kellar KJ, Wainer IW. Anal Biochem. 1998; 264:22-25. [PubMed: 9784183]

21. Simons K, Ikonen E. Nature. 1997; 387:569-572. [PubMed: 9177342]

22. Tsui-Pierchala BA, Encinas M, Milbrandt J, Johnson EM Jr. Trends Neurosci. 2002; 25:412-417. [PubMed: 12127758]

23. Sprenger RR, Horrevoets AJ. Methods Mol Biol. 2007; 357:199-213. [PubMed: 17172689]

24. Li N, Shaw AR, Zhang N, Mak A, Li L. Proteomics. 2004; 4:3156-3166. [PubMed: 15378691]

25. Foster JL, De Hoog CL, Mann M. Proc Natl Acad Sci USA. 2003; 100:5813-5818. [PubMed: 12724530]

26. Madore N, Smith KL, Graham HC, Jen A, Brady K, Hall S, Morris R. Eur Mol Biol Org. 1999; 18:6917-6926.

27. Yu P, Yang Z, Jones JE, Wang Z, Owens SA, Mueller SC, Felder RA, Jose PA. Kidney Int. 2004; 66:2167-2180. [PubMed: 15569306]

28. Bruses JL, Chauvet N, Rutishauser U. J Neurol. 2001; 21:504-512.

29. Oshikawa J, Toya Y, Fujita T, Egawa M, Kawabe J, Umemura S, Ishikawa Y. Am J Physiol Cell Physiol. 2003; 285:C567-C574. [PubMed: 12748066]

30. Banerjee P, Joo JB, Buse JT, Dawson G. Chem Phys Lipids. 1995; 77:65-78. [PubMed: 7586093]

31. Ostrom RS, Gregorian C, Drenan RM, Xiang Y, Regan JW, Insel PA. J Biol Chem. 2001; 276:42063-42069. [PubMed: 11533056]

32. Moaddel R, Calleri E, Massolini G, Frazier C, Wainer IW. Anal Biochem. 2007; 364:216-218. [PubMed: 17391632] 


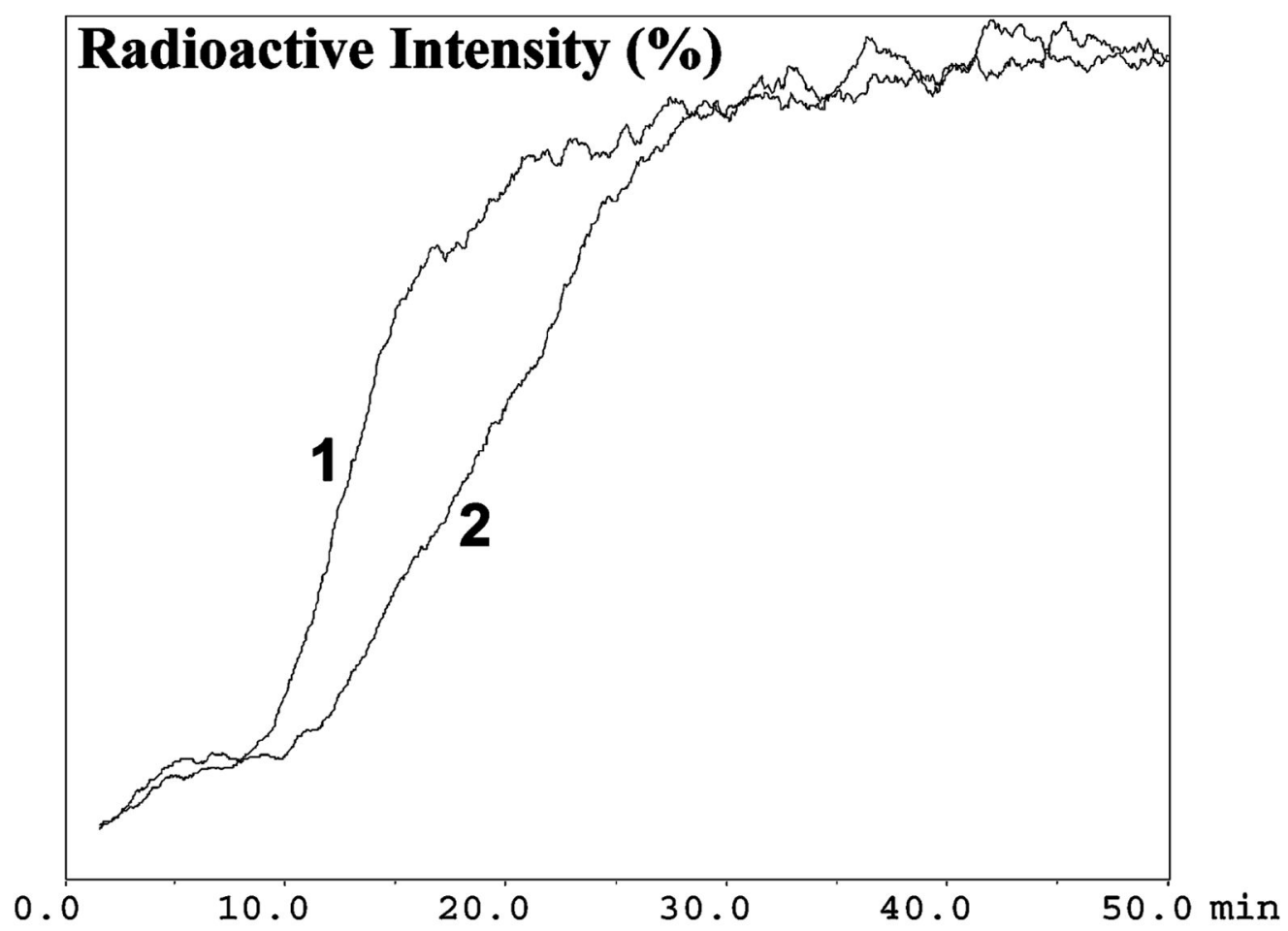

Figure 1.

Competitive displacement of $\left[{ }^{3} \mathrm{H}\right]$-nicotine on the $\mathrm{a} 7(+)$ nAChR-IAM, where chromatographic traces 1 and 2 represent the chromatography of $120 \mathrm{pM}\left[{ }^{3} \mathrm{H}\right]$-nicotine alone and in the presence of $500 \mathrm{pM}$ nicotine, respectively. Running buffer: ammonium acetate $(10 \mathrm{mM}, \mathrm{pH} 7.4), 10 \mathrm{pM}$ cholesterol at a flow rate of $0.2 \mathrm{~mL} / \mathrm{min}$. 

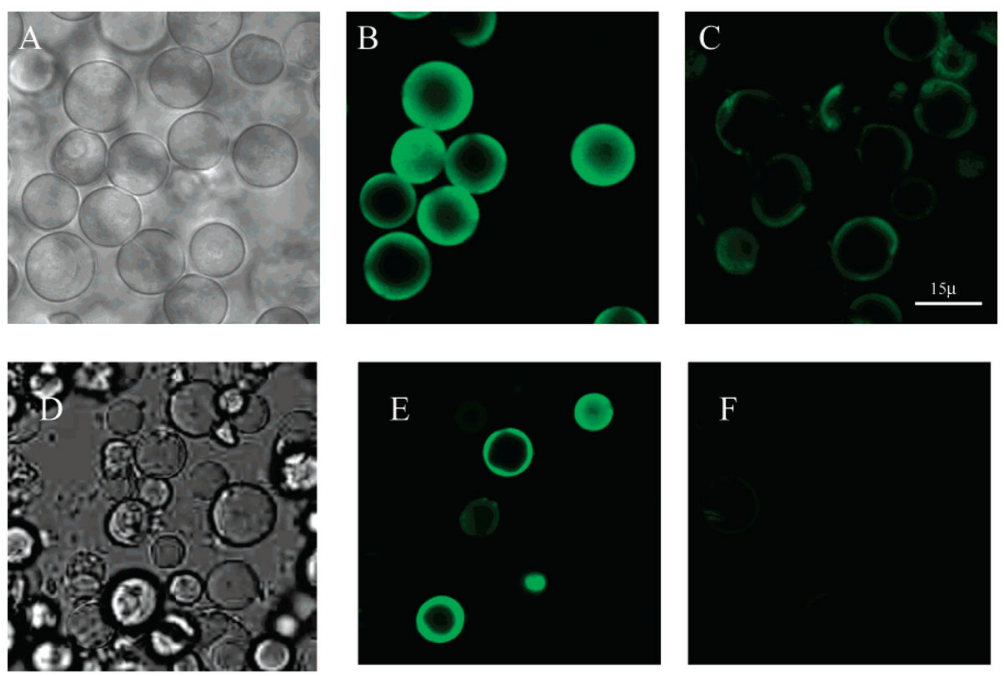

Figure 2.

FITC-labeled a-bungarotoxin (FITC-a-Bgt) $(1 \mathrm{mg} / \mathrm{mL})$ pumped through an ha7(+) nAChRSH-EP1 IAM column and a7(+)-nAChR-HEK-293 IAM column during 30 min using a peristaltic pump (Dynamax RP-1) at a flow rate of $50 \mu \mathrm{L} / \mathrm{min}$ followed by water for $30 \mathrm{~min}$. The transmitted light images are displayed in (A) and (D), respectively, and the fluorescent images are displayed in (B) and (E). FITC-a-Bgt was also pumped through the ha7(-) nAChR-SH-EP1 IAM column and the a7(-) nAChR-HEK-293 IAM column. The fluorescent images are displayed in $(\mathrm{C})$ and $(\mathrm{F})$, respectively. A small amount of stationary phase was collected and analyzed by confocal microscopy. The stationary phases were imaged with a Zeiss LSM-410 inverted confocal microscope with excitation at $488 \mathrm{~nm}$ and collecting emission at greater than $515 \mathrm{~nm}$ simultaneously with transmitted image using a Zeiss Plan-Apochromat 63x/1.4 NA oil immersion lens. The images were processed by MetaMorph software. 
Table 1

Binding Affinities, $K_{\mathrm{d}}$ Values, Calculated by Frontal Affinity Chromatography on the a 7 nAChR and $a 4 \beta 2$ nAChR CMAC Columns Prepared in This Study

\begin{tabular}{|c|c|c|}
\hline \multirow[b]{2}{*}{ cell type } & \multicolumn{2}{|c|}{$K_{\mathrm{d}}(\mathrm{nM})$} \\
\hline & epibatidine & nicotine \\
\hline SH-EP1-ha7 & 0.67 & 7,610 \\
\hline SH-EP1-ha $4 \beta 2$ & 0.46 & 12.80 \\
\hline a7 HEK-293 & 0.82 & 5,590 \\
\hline a $4 \beta 2$ HEK-293 ${ }^{a}$ & 0.01 & 16.40 \\
\hline
\end{tabular}

${ }^{a}$ Data previously reported. 
Table 2

Composition of the Solubilization/Immobilization Buffers Used in the Preparation of CMAC Columns ${ }^{a}$

\begin{tabular}{llll}
\hline cell type & receptor & detergent & additive \\
SH-EP1 & $a 7 \mathrm{nAChR}$ & $2 \%$ cholate & $\mathrm{CH}, \mathrm{PS}, \mathrm{PE}$ \\
SH-EP1 & $a 4 \beta 2 \mathrm{nAChR}$ & $2 \%$ cholate & $\mathrm{PS}, \mathrm{PE}$ \\
HEK-293 & $a 7 \mathrm{nAChR}$ & $2 \%$ cholate & $\mathrm{CH}$ \\
HEK-293 $b$ & $a 4 \beta 2 \mathrm{nAChR}$ & $2 \%$ cholate & \\
HEK-293c & $\beta 2 \mathrm{AR}$ & $2 \%$ cholate or CHAPS & PC \\
\hline
\end{tabular}

${ }^{a}$ Where nAChR is nicotinic acetyl choline receptor, AR is adrenergic receptor, $\mathrm{CH}$ is cholesterol, $\mathrm{PS}$ is L-a-phosphatidylserine, $\mathrm{PE}$ is L-aphosphatidylethanolamine, and PC is mixed egg phosphatidylcholine.

${ }^{b}$ Data obtained from ref 17 .

${ }^{c}$ Data obtained from ref 25 . 